\title{
Legal Uncertainty of Islamic Personality Principle by Supreme Court Circular Letter Number 8 Year 2010
}

\author{
Rahadi Wasi Bintoro \\ Departement of Procedural Law \\ Universitas Jenderal Soedirman \\ Purwokerto, Indonesia \\ rahadiwasibintoro@gmail.com
}

\author{
Tedi Sudrajat \\ Department of Administrative Law \\ Universitas Jenderal Soedirman \\ Purwokerto, Indonesia \\ tedi.unsoed@gmail.com
}

\begin{abstract}
The increasing competence of religious courts in Indonesia still creates a polemic for its competence of other judiciary institutions. It happens due to the clash of rules and the issuance of Supreme Court circular letter. This paper discusses the solution to the clash of rules and shows the existence of Supreme Court circular letter in the legislation system of Indonesia. This issue will be resolved by statutory approach and conceptual approach. Based on the analysis, the clash of rules can be solved by using lex specialis derogat legit generali principle as lex specialis is religious judicial law and lex generalis is judicial power law. Circular letter is not a form of law; thus, it should not provide conflict.
\end{abstract}

Keywords: clash of rules; competence; policy regulations

\section{INTRODUCTION}

Sharia economics as part of Islamic teachings [1] grew rapidly in the early 1970s [2]. The development of sharia economy is a criticism [3] of the existing economic system at the time which ignores the importance of social welfare. As a result, its development is only felt by certain circles.

In 2006 there was a revolutionary change [4] in religious judiciary, because the existence of religious courts was strengthened by the addition of its competence to the settlement of sharia economic dispute. The development of Religious Courts competence until this time still leaves a polemic on the uncertainty itself, because there is still an overlap with other legislations. One of the overlapping rules occurred was competence of the judiciary on the annulment/ execution of the Decision of the National Sharia Arbitration Board, since there are at least two different Laws, Article 59 paragraph (3) of Law Number 48 Year 2009 on Judicial Power (hereinafter referred to as the Judicial Power Law) regulating the annulment/ execution of Decision of National Sharia Arbitration Board which is the competence of General Court Article 1 of Law Number 50 Year 2009 and Article 49 of Law Number 3 Year 2006 and (hereinafter referred to as the Religious Judicial Law) implicitly regulating it is a competence of the Religious Courts. Finally, the Supreme Court issued Circular Letter No. 8 Year 2008 emphasizing that Religious Courts are competent in the case of the Corresponding authors : Rahadi Wasi Bintoro implementation / annulment of the Decision of the National Sharia Arbitration Board; however, in 2010 the circular letter shall be declared invalid and replaced by Circular Letter of Supreme Court Number 8 Year 2010 (hereinafter abbreviated to the Circular Letter of the Supreme Court) stating otherwise on the basis of Article 59 of Law Number 48 Year 2009. The existence of the two circulars indicates the Court doubt to determine the competence of the annulment of the National Sharia Arbitration Board Decision.

Therefore, this study will analyze the overlapping rules in which the solutions will be found by solving the overlapping rules on the competence of the annulment of the Sharia Arbitration Board's decision and whether it is appropriate that the circular letter is addressed to judge in his capacity as a judge; should the judge be independent?

\section{RESEARCH METHOD}

This paper is a part of legal researches and to answer the problem, the approach method used is a concept and legislation approach. Therefore, the primary source of legal material is the legislation relating to the object of this study, they are Law Number 12 Year 2011, Law Number 7 Year 1989, Law Number 3 Year 2006, Law Number 50 Year 2009 and Law Number 48 Year 2009, and it is supported by secondary legal materials, in the form of literature for instance books and scientific journals. After the source of legal material is collected, then qualitative analysis is conducted by describing the data quality in the form of a regular, coherent, logical, non-overlapping and effective sentence, thus it is facilitating the interpretation of the data.

\section{RESULT AND DISCUSSION}

The independency of judiciary power can be regarded as a reflection of Universal Declaration of Human Rights [5], and International Covenant on Civil and Political Rights, which regulates the independent and impartial judiciary. [6] In order to realize the state of law [7], the provision requires a judiciary established by an independent, impartial and competent judiciary, and an honest and openly examination held in court [8]. All of these elements 
have been accommodated in the 1945 Constitution and passed in Judicial Power Law.

Judicial authorities in Indonesia are Supreme Court and its subordinate courts (General Courts, Religious Courts, State Administrative and Military Courts) and Constitutional Court. Each of the judicial authorities has its own absolute competence in order to avoid a dispute over the authority to hear and for the creation of legal certainty.

Two judicial institutions which often overlap in their competences until this day are Religious Courts and General Courts. The overlap is the occurrence of overlapping rules to judge cases of implementation / annulment of the decision of the National Sharia Arbitration Board, whereas in Article 59 Paragraph (3) of the Judicial Power Law, it becomes the competence of the district courts under the general judicial environment. Meanwhile, Article 49 of the Religious Judicial Law implicitly asserts that the implementation of the decision of the National Sharia Arbitration Board is its competence in accordance to the principle of Islamic personality characteristic of the case in the Religious Courts.

In the case of overlapping rules, the principle must in line with principle of law, in this case the principle of preference which is lex specialis derogat legi generali, where a specific rule puts aside the general rules. Therefore, it is necessary to be studied in depth, which of the two laws are lex specialis and which are generalists.

Based on Article 7 paragraph 1 of Law Number 12 Year 2011, Judicial Power Law has a vertical relationship with the 1945 Constitution and the decree of MPR, and has a horizontal relationship with the law of other judicial parties, such as the Supreme Court Law, General Court Law, Religious Court Law, State Administrative Justice Law, Military Justice, Constitutional Court Law.

Law Number 7 Year 1989 on Religious Courts may be considered obsolete in the $2000 \mathrm{~s}$, because it has not regulated the dispute resolution of sharia economy. On the other hand, the sharia wheel economy is in its momentum at that moment. In order to accommodate the development of sharia economic in settling of disputes, then in 2006 it was issued Law Number 3 Year 2006 on amendment to Law Number 7 Year 1989 on Religious Courts. Under this law, the Religious Court is one of the judicial institutions of the judicial authorities to provide law enforcement and justice for people in seeking justice among Moslems in the field of marriage, inheritance, will, grant, waqf, zakat, infaq, shadaqah, and sharia economics. To strengthen its existence, in 2009 a second amendment of Law Number 7 Year 1989 was done through Law Number 50 Year 2009. There is a distinctive feature of the Religious court in Article 49 of Law Number 3 Year 2006 and Article 1 of Law Number 1 Number 50 Year 2009, the difference is that the religious court is a judicial law applicable to an Islamic law matter and its legal relationship is done with the principles of sharia (Islamic Law). Then, this provision is referred to the principle of Islamic personality. Thus, Judge, as a justice seeker must also have a specification as an Islamic law expertise and this makes Religious Court different with the other judiciaries.

Beside the needs of society, the amendment of religious judicial law is conducted to adjust with the law of judicial authority in horizontal relationship. It is because judicial authority law has amendment, in which in 1970, there is Law Number 14 Year 1970 on judicial authority which then changed with Law Number 35 Year 1999 on the amendment of Law Number 14 Year 1970 on Basic Stipulations of Judicial Authority, then it is changed with Law Number 4 Year 2004 on Judicial Authority and lastly that law is changed to be Law Number 48 Year 2009. To adjust with Law Number 4 Year 2004, Law Number 7 Year 1989 gets amendment in Law Number 3 Year 2006 and to adjust with Law Number 48 Year 2009, Law Number 7 Year 1989 gets twice amendments through Law Number 50 Year 2009.

The existence of Judicial Authority Law is correlated to the amendment of 1945 Constitution. In 2002, the amendment of 1945 Constitution had been conducted. That amendment had brought change on constitutional system, especially to judicial authority; therefore, law of judicial authority in vertical relationship must be adjusted and in 2009, there was Law Number 48 Year 2009 on judicial authority replacing previous law namely Law Number 4 Year 2004.

Hence, it can be concluded that in horizontal relationship, Law of Religious Court is always adjusted with Judicial Authority Law. It aims to create harmonization in the statutes. Harmonization of statutes refers to lex specialis derogat legi generali principle. This principle refers to two statutes which hierarchically have the same position, but the scope of materials between two statues is different, in which one of them is special regulation from another.

Based on the explanation above, the clash between Article 59 section (3) of Judicial Authority Law and Article 49 of Religious Judicial Law can be overcome by lex specialis derogat legi generali principle. In this case, lex specialis is Religious Judicial Law, meanwhile lex generalis is Judicial Authority Law. It is because Law of Judicial Authority is general rule which regulates the implementation of judicial authority; on the other hand, Religious Judicial Law is special regulation for its implementation of judicial authority by Religious Court. This case becomes the absolute competence of Religious Court if it is correlated to verdict posponement case of National Sharia Arbitration Board because the dispute filed to National Sharia Arbitration Board happens in a legal relationship based on Islamic principle. The use of Islamic principle in a legal relationship is a special characteristic of Islamic personality principle which becomes the absolute competence of Religious Court.

Therefore, it can be seen clearly that Circular Letter of Supreme Court Number 8 Year 2010 is 
contradicted with lex specialis derogat legi generali principle. The next question is whether the judge must follow that circulation letter or not. Hence, the existence of circular letter in administrative law needs to be studied further.

Circular letter in administrative law is known as policy rules. In Holland, the forms of state administrative decision can be divided into: First, Decisions which contain statutes (algemene verbindende voorschriften); Second, Decisions that contain determination (beschikkingen); Third, Decisions which is not the statutes but having general consequence; Fourth, Decisions that contain planning (plannen); and Fifth, Decisions that contain policy rules (beleidsregels) [9].

Policy rules (beleidsregel, spiegelsrecht, pseudowetgeving atau policy rules) are stipulation (rules are not law) made by government as state administration in which the implementation of that authority is not based on the statutes stipulation, but based on freedom to act principle beleidsvrijheid atau beoordelings vrijheid) or well known as freies Ermessen [10].

In making the policy regulation, several things should be noted: First, the Policy Regulation is not (excluding) a form or type of statutory law, although in many cases it appears (showing symptoms) as statutory law. Second, the implementation of the policy is not settled in the form of statutory law. Third, as a "rule" that is not a statutory law; policy regulations are not directly binding legally but contain legal relevance. Fourth, the policy regulation is essentially addressed to the state's own administrative bodies or officials. Fifth, the enactment of a policy regulation is necessary in order to ensure that compliance not only applies to actions that are sourced or based on laws and regulations, but also applies to acts based on freedom of action. Sixth, the form of policy regulation is formulated information in general and in writing. Seventh, since the regulatory policy is not a statutory law, the principles of restriction and testing of laws and regulations cannot be applied to the policy regulations. Eighth, Tests on policy regulation are more directed at doelmatigheid and therefore the testing stone is the general principles of good governance. Ninth, to avoid policy regulation beyond the limits of freedom of action and undermine the prevailing legal order, it is necessary to find principles that could be in control of policy regulation. These principles include the principles of the lawbased state, the principles of people protection and the general principles of the proper administration of state administration. Beyond these principles, policy regulation is no longer within the framework of the Ermessen freies, but can be arbitrary [11]. Thus, the policy regulation issued within the framework of freies ermessen still rests the laws and regulations, in order to avoid arbitrary action.

Based on the explanation, it can be seen that Circular Letter of the Supreme Court Number 8 Year 2010 is a policy regulation issued within the framework of freies ermessen. However, it should be explored whether the policy regulation is arbitrary or not.

As previously discussed, the Supreme Court Circular Letter Number 8 Year 2010 has canceled the Circular Letter of the Supreme Court Number 8 Year 2008. Circular Letter of the Supreme Court Number 8 Year 2008 explicitly states the implementation of decision of the National Sharia Arbitration Board is a competence of Religious Courts based on the provisions of Article 49 of Law Number 3 Year 2006 and also implicitly mention that the annulment of National Arbitration Board Decision also included in the competence of Religious Court, considering the decision of Sharia Arbitration Board related to sharia economic dispute. The provisions in this Circular Letter, if related to the principle of Islamic personality, then the provisions in the circular letter are appropriate. However, the circular letter shall be declared invalid through the circular letter of the Supreme Court Number 8 Year 2010. This latest circular letter provides the implementation (including annulment) of the decision of the National Sharia Arbitration Board is the competence of the district court under the general court environment under Article 59 paragraph (3) of Law Number 48 Year 2009.

These two circular letters in turn implicate the judges' ruling, as mentioned before. Central Jakarta Religious Court ruling Number 792 / Pdt.G / 2009 / PA.JP under the background of Sema Number 8 Year 2008 declare that he is authorized to examine the cancellation of the Decision of the National Sharia Arbitration Board, which is then filed an appeal to the Supreme Court and has been rendered Decision Number 188 K / AG / 2010 and reinforced by Judicial Review Decision Number 56 PK / AG / 2011. The two final judgments were also inspired by the circular letter of the Supreme Court; however it is not the circular letter of the Supreme Court Number 8 Year 2008, instead circular letter Number 8 Year 2010.

The circular letter proved to influence the judge in making his decision. Please note, that the judge has dual roles in carrying out his duties. First, the judge as a judge, he must explore, follow, and understand the values of law and sense of justice that live in society. Secondly, judges as state officials, namely state officials under the Supreme Court, here the judge must obey the rules in place of shelter.

For judges as a judge, they should have independence principle. The principle of independence of judicial authority is regulated in Article 24 paragraph (1) of the 1945 Constitution that the Judicial Authority is an independent power to administer justice in order to uphold law and justice. This independence is reaffirmed in Article 1 number 1 of Law Number 48 Year 2009, that "Judicial Power is the power of an independent state to administer the judiciary to uphold law and justice pursuant to Pancasila and the Constitution of the State of the Republic of Indonesia Year 1945, for the 
implementation of the State of the Republic of Indonesia", then Article 3 paragraph (1) of Law Number 48 Year 2009 stipulates that "In carrying out its duties and functions, the judges and judges of the constitution shall maintain the independence of the judiciary", in its elucidation what is meant by "judicial independence" is free from outside interference and free from any form of pressure, physical or psychological.

The independence of judicial power is indispensable for the guarantee of human rights and the defense of justice which is an essential element in a democratic state, between democracy and law is not understood as two contradictory entities in terminis where they can be in a peaceful co- existence) without any of the superior of the others because they are all important in the notion of a modern state [12].

The influence of the judge in the judgment, in the case, in essence has violated the principle of independence itself and has restricted the independence of judges to be free in giving their legal considerations on the basis of prevailing laws and regulations. As previously analyzed, the clash of rules of implementation / annulment of the decision of the national sharia arbitration institution can be solved based on the principle of lex specialis derogat legi generali, whereas lex specialis is Law Number 3 Year 2006 and its lex generalis is Law Number 48 Year 2009.

It should be emphasized that circulars letters are not source of law and certainly should not be used as a backdrop for judges to impose their breaks. Circular letters affecting judges in decision-making have in fact interfered with the independence of judges. Moreover, the Supreme Court Circular Letter Number 8 Year 2010 "order" judges under his jurisdiction to examine and adjudicate cases of the implementation / annulment of the decision of the National Sharia Arbitration Board in a public court under the General Courts of Article 59 of Law Number 48 Year 2009. In fact, in making a verdict, the judge must be independent and prioritize justice. It is fatal, when a circular letter is attached to the judge's duties as a judge, thereby reducing the judge's independence in examining the case. In this case the judge will surely follow the circular letter issued by the Supreme Court as one of his integrity as a state official under the Supreme Court. If the explanation refers to the Circular Letter of the Supreme Court, in fact the Supreme Court has interfered with the independence of the judge, because the circular letter "ordered" the judge under his jurisprudence to examine and adjudicate the case of decision implementation of the National Sharia Arbitration Board in the district court under the general court environment under Article 59 of Law Number 48 Year 2009. In fact, in making a verdict, the judge must be independent and prioritize justice. A fatal thing, when a circular is attached to the duties of a judge as a judge, thereby reducing the independence of the judge in examining the case.

\section{IV.CONCLUSION}

Clash of rules in Article 59 paragraph (3) of Law Number 48 Year 2009 with Article 49 of Law Number 3 Year 2006 can be completed with lex specialist derogat legi generali principle, in this case as lex specialis is Law Number 3 Year 2006 and as lex generalis is Law Number 48 Year 2009. Supreme Court Circular Letter Number 8 Year 2010 has violated the independence of judges to examine and adjudicate a case and in its capacity as an announcement, the circular letter shall be ignored.

\section{REFERENCE}

[1] Ahmad, "Settlement of Sharia Economic Dispute in Religious Courts" (Penyelesaian Sengketa Ekonomi Syariah di Pengadilan Agama), Jurnal Ius, Vol. 2, No. 6, pp. 476488, 2014.

[2] A. Mehmet. "Conceptualisation of The Second Best Solution In Overcoming The Social Failure of Islamic Banking And Finance: Examining The Overpowering of Homoislamicus By Homoeconomicus, IIUM Journal of Economics and Managemen, 15 No. 2, pp. 167-195, 2007; also see Z., M. Raquibuz and M. Hormoz. "Islamic Banking a Performance Analysis", The Journal of Global Business, Vol. 12 No. 22, pp. 31-38; M. Iqbal and M. Philip, "Thirty Years of Islamic Banking: History, Performance and Prospects", J.KAU: Islamic Econ., Vol. 19, No. 1, pp. 37-39, 2001.

[3] J. R. Presley, and J. G. Sessions,. "Islamic Economics: The Emergence of a New Paradm". The Economic Journal, 104 (may), pp. 584-596, 1994.

[4] Khisni, Religious Courts as Family Courts and the Development of Islamic Law Studies in Indonesia (Peradilan Agama Sebagai Peradilan Keluarga serta Perkembangan Studi Hukum Islam di Indonesia), Jurnal Hukum, Vol. XXV No. 1, pp. 490-415, 2011; also see Matrais, Sumadi, "Kemandirian Peradilan Agama dalam Perspektif Undangundang Peradilan Agama", Jurnal Hukum, Vol. 15 No. 1, pp. 121-144, 2008.

[5] United Nation, Universal Declaration of Human Rights paragraf $10, \quad$ available on http://www.un.org/en/udhrbook/pdf/udhr_booklet_en_web.p df

[6] O. S. Adji, Judicial Free State Law (Peradilan Bebas Negara Hukum), Jakarta: Erlangga, 1998.

[7] D. Gusman, and A. Nova, "Position of People Consultative Council Decree Based on Law no. 12 of 2011 on the Establishment of Legislation" (Kedudukan Ketetapan MPR Berdasarkan UU No. 12 tahun 2011 tentang Pembentukan Peraturan Perundang-undangan), Jurnal Dinamika Hukum. Vol. 12 No. 2. Pp. 437-447, 2012. ; M. Fauzan, "The existence of the Judicial Commission in the Structure of the State of the Republic of Indonesia and which should be Regulated in Legislation" (Eksistensi Komisi Yudisial Dalam Struktur Ketatanegaraan Republik Indonesia dan yang Seharusnya Diatur dalam Peraturan perundang-undangan), Jurnal Dinamika Hukum. 2008. Vol. 8 No. 1. Pp. 43-50, 2008. ; J. Simamora, "The Meaning of the Law in Perspective of the Constitution of the Republic of Indonesia Year 1945" (Tafsir Makna Hukum Dalam Perspektif Undang-undang Dasar Negara Republik indonesia Tahun 1945), Jurnal Dinamika Hukum, Vol. 14, No. 3. Pp. 547-561, 2014. 
[8] N. Qamar, "Independence of Judges in implementation Power of Justice", Jurnal Dinamika Hukum, Vol. 15 No. 1. Pp. 51-56, 2015.

[9] Manan and K. Magnar. Some Problems of Indonesia's Constitutional Law (Beberapa Beberapa Masalah Hukum Tata Negara Indonesia), Bandung: Alumni, 1997.

[10] Manan and K. Magnar. Some Problems of Indonesia's Constitutional Law (Beberapa Beberapa Masalah Hukum Tata Negara Indonesia), Bandung: Alumni, 1997.

[11] Manan and K. Magnar. Some Problems of Indonesia's Constitutional Law (Beberapa Beberapa Masalah Hukum Tata Negara Indonesia), Bandung: Alumni, 1997.

[12] A A. Thohari, Democracy as well as Nomocracy (Demokrasi sekaligus Nomokrasi), Kompas, $7^{\text {th }}$ November 2003 